\title{
Research on the silver in the world flowing into Qing Dynasty
}

\section{Jun Wei}

Minnan Normal University

\begin{abstract}
In the 80 years of foreign trade in the Qing Dynasty, the main flow direction of silver was from Spain and Britain to Qing Dynasty, which is one of the main contents; the other is the materials, process and variety design of the silver flowing into the Qing Dynasty.
\end{abstract}

Keywords: Flow direction of silver; Casting of silver; Type of silver

DOI: $10.36012 /$ ems.v1i1.960

$\mathrm{F}$ rom 1757 to 1833 , there was a strong trend that silver flowed into the Qing Dynasty. At this time, the international silver resources were concentrated in Mexico, Peru, Argentina, Bolivia, Brazil and other places in South America, Canada, Mexico, the United States in North America, as well as Australia and Japan. Mexico, Peru, Argentina and Bolivia became Spanish colonies in 1538, 1521, 1533 and 1535, respectively. Since 1500, Brazil became a colony of Portugal, Spain, Holland and France. In 1607, 1763 and 1770, the United States, Canada and Australia were included in the British colonial sphere of influence. Japan banned silver exports to the Qing Dynasty from 1760. Spain, Britain and the United States were important partners of the thirteen foreign trade groups in the Qing Dynasty. It is through the legal way of foreign trade with these countries that a large number of silver poured into the Qing Dynasty.

\section{A survey of silver flowing from Spain into Qing Dynasty}

Spain acquired the resources of the Potosi silver mine in Peru and the Zacatecas silver mine in Mexico in 1545 and 1548, respectively, through colonization and plunder. Among them, the Potosi silver mine is the most famous one. During the period from 1581 to 1600 , the average annual silver output of Potosi silver mine reached $254,000 \mathrm{~kg}$, accounting for more than $60 \%$ of the world's average annual silver output at that time. From 1624 to 1634 , the annual average silver production of the silver mine reached 523.2425 pesos (1 Piaster $=0.7$ Liang silver). Silver production in America accounted for $75 \%$ of the world's total silver production in the 16 th century, $84.4 \%$ in the 17 th century and $89.5 \%$ in the 18 th century. Before silver mines were discovered and mined in America, the price of gold and silver in Europe was between 1:10 and 1:12. With the increase of production, the price of silver gradually fell. By the middle of the 17th century, the price of gold and silver in Europe had dropped from $1: 14$ to $1: 15$.

Spanish natives swarmed to colonize and develop the gold mountain silver mines in America, and a large amount of silver flowed into Spain. Spain imported agricultural and manufacturing products from other countries to meet the daily needs of the colonies. In the Qing Dynasty, silver was very expensive, but silk, cotton and other items priced in silver were very cheap. Spanish officials thought that a large number of items provided by the Qing Dynasty were so cheap that they could hardly be bought with silver. In Peru in 1640, the price of goods such as silk and porcelain in the Qing Dynasty was only one-third of the same goods from Spain. These low-priced Chinese goods could be sold in Manila, a Spanish colony, and could make $100 \%$ to $300 \%$ of profits when they were sold in America. British and Indian companies hired sailors and captains from Asia to bribe Spanish officials and enter the Manila market. The kind of silver, Manila yacht is famous for its material, which was transported 
from the new world to Manila to purchase Chinese silk and other products. Silver therefore surged from Spain through Manila to the Qing Dynasty.

\section{A survey of silver flowing Britain and America into Qing Dynasty}

Silver from other countries in the world also flowed to the Qing Dynasty with foreign trade. Britain's trade with China has been booming since 1785, and the value of its trade with China in each of the following four years has reached 3,612,763 liangs of silver. In the first four years of the 19th century, the average annual import value was 7,715,556 liangs of silver. From 1805 to 1806 , Britain's trade with China was the most prosperous, and the value of goods traded with China in this year reached more than 10 million. The reason was that in 1805 , Britain first defeated France with the alliance of Russia and Austria, and then the Royal Navy defeated the combined fleet of France and Spain, securing the maritime hegemony. In China's trade, the United States was a latecomer. In the first four years of China-US trade, the annual value of goods in China's trade was less than 30,000 liangs of silver. It began to rise to more than 100,000 liangs in 1785 . In the four years at the end of the 18th century, the annual trade value with China reached 374,124 liangs of silver. After entering the 19th century, the volume of US trade with China increased, and the value of goods exported to China reached more than 800,000 liangs. After 1820, the value of American trade with China was nearly 1.5 million liangs. In the first three years when the British and Indian companies lost their monopoly rights, the value of goods traded between the United States and China reached 1,766,692, accounting for $19.2 \%$ of the total trade between European and American countries with China. After the French Revolution and the Napoleonic Wars (1803-1815) in the late 18th century, the trade between other European countries with China dropped sharply to more than 162,000, far less than that between Britain and the United States. After 1825, the value of goods dropped to tens of thousands of liangs of silver. "The Danes and Swedes withdrew from Guangzhou years before 1825. At that time, there were no French businessmen doing business in Guangzhou. From 1802 to 1832, the French flag had not been raised in the past 30 years, and even the personnel have been removed... In 1832 Spain cut off its dismal business in the Qing Dynasty. "

Table 1. The amount of silver shipped to China from European and American countries in 1764-1833

\begin{tabular}{|c|c|c|c|c|}
\hline Period & $\begin{array}{c}\text { Europe and America sea } \\
\text { Total trade value }\end{array}$ & $\begin{array}{c}\text { Britain } \\
\text { Total trade value }\end{array}$ & $\begin{array}{c}\text { U.S.A } \\
\text { Total trade value }\end{array}$ & $\begin{array}{l}\text { Total trade value of other } \\
\text { European countries }\end{array}$ \\
\hline 1764 & $1,908,704$ & $1,207,784$ & - & 700,920 \\
\hline $1765-1769$ & $1,774,815$ & $1,192,915$ & - & 581,900 \\
\hline $1770-1774$ & $2,094,336$ & $1,466,466$ & - & 627,870 \\
\hline $1775-1779$ & $1,995,913$ & $1,247,471$ & - & 748,442 \\
\hline $1780-1784$ & $1,994,617$ & $1,301,931$ & 27,290 & 665,396 \\
\hline $1785-1789$ & $4,489,527$ & $3,612,763$ & 123,164 & 753,600 \\
\hline $1790-1794$ & $5,876,663$ & $5,007,691$ & 181,096 & 687,876 \\
\hline $1795-1799$ & $5,908,937$ & $5,373,015$ & 374,124 & 161,798 \\
\hline $1800-1804$ & $8,727,364$ & $7,715,556$ & 828,326 & 183,482 \\
\hline $1805-1806$ & $12,348,319$ & $11,474,509$ & 767,775 & 106,035 \\
\hline $1817-1819$ & $9,053,298$ & $7,646,777$ & $1,184,551$ & 221,970 \\
\hline $1820-1824$ & $7,952,488$ & $6,525,201$ & $1,427,287$ & - \\
\hline $1825-1829$ & $9,161,314$ & $7,591,390$ & $1,534,711$ & 35,213 \\
\hline $1830-1833$ & $9,192,608$ & $7,335,023$ & $1,766,692$ & 90,893 \\
\hline
\end{tabular}

Source: Y an Zhongping: selected statistics of modern economic history of China, Beijing: Science Press, 1955, P. 4. The annual value is the annual average. 


\section{Materials, process, design of casting of sil- ver flowing from Britain into Qing Dynasty}

Therefore, during the existence of Thirteen Hongs of Canton, most of the silver inflow was brought by British and American merchant ships. The inflow of silver was called foreign money or silver. It only circulated silver. From the middle and late Qianlong period in the 1860s and 1970s, foreign silver was made by machine, its weight and color were standardized, and its style was regular and exquisite. In the commercial exchanges in the coastal areas, "counting the core value" gradually showed the advantages of the Qing silver, which was "higher than silver" and "heavier than two".

The circulation of foreign silver was the most unblocked in Central America. This kind of silver was called Benyang in the early stage and later became Yingyang. Benyangwas the Spanish silver dollar, which was most popular among businessmen and people. The Spanish silver dollar had a king's head, also known as Buddha's head or old man's head. It's a Garola IV silver dollar. It's forged in Mexico. It's more than half of China's Kupingtael. It contained $902.78 \%$ o pure silver. In 1814, Benyang in Guangzhou "exchanged 7,230 yuan for money (copper money)." there was an American silver dollar and an old Mexican lace silver dollar. After circulation, there were a lot of exchange records between the two currencies. After the independence war in Mexico in 1821, the production of Benyang stopped, which caused the rapid growth of the price of Benyang. Due to the shortage of supply, Spain's foreign currency was priced higher than its real value, which led to the phenomenon of rising water; while the other two types of Spanish silver dollar, i.e. Garola III and Ferdinand VII, had the same advantages as the foreign currency, but they need to be favorable to the foreign currency.

After honyang, it was Yingyang. At the beginning of its circulation, it was not smooth. Although its silver content was the same as that of honyang, it was rejected. Compared with honyang, a discount of $20-30 \%$ was needed. After 1823, Yingyang replaced Benyang. Alfred Wilkinson, a manager of Bell's agency in England, had been working in Guangdong since 1835 . He admitted that "I can provide a fact related to the currency operation in Guangzhou. I used to exchange a certain amount of silver dollars for another kind of silver dollars, from which I gained $20 \%$ of the profits. Although the intrinsic value of these silver is the same. I sell it at a discount of $14 \%$ to $15 \%$, and then I buy the Mexican silver dollar and the Republic silver dollar of South America at a discount of $6 \%$ to $7 \%$.

In addition to Spanish silver dollar, the copper money of Vietnam and Japan, i.e. foreign money, was widely circulated in the Qing Dynasty. The silver dollar from Japan is called kuanyongTongbao, which is mainly distributed in Ningbo, Shanghai and other places. Vietnam's JingxingTongbao, JingxingJubao, etc., are mostly circulated in Chaoshan, Fujian Quanzhou and other places in Guangdong

The silver dollar from the United States designed as Washington head, 15 stars and free English spelling. The date is 1795 . On the back of the silver dollar was osman thus surrounded by an eagle and the English spelling of the United States of America. The U.S. silver dollar wasof the same weight as the foreign currency, except for a slightly higher copper content. These foreign silver dollars were quite different in discount rate because of different preferences of Chinese people.

During the period of foreign trade, from 1757 to 1842 , foreign businessmen paid the tariff through the Spanish silver dollar of thirteen merchants, and then the merchants changed the Spanish silver dollar into silver and paid ingots to the state treasury.

\section{References}

[1] Anne wilbraham, Jack C. Drummond. The Englishmen's Food: A History of Five Centuries of EnalishDiet . ( London: Vintage. 1994.

[2] Andre Gunder Frank. ReOrient: Global Economy in the Asian Age. California: University of California Press, 1998.

[3] C.F.Remer . The Foreign Trade of China. Tapei: Ch'eng-Wen Publishing Co. .1967.

[4] C.R. Boxer. Fidalgos in the Far East, 1550-1770. The Hauge: Martinus Nijhoff, 1948

[5] Liu Qiang'an. Anti-money laundering of securities companies driven by financial science and technology[J].Western Finance and Accounting. No.8,2018.

[6] WeiJun. The process of silver monetization in Ming Dynasty and Its Enlightenment.Qiusuo.No.1,2016. 